\title{
Historic Sites in the Upper Assiniboine River
}

\author{
W. Yanchinski, Naicam, Sask.
}

\section{A} FEW YEARS BACK the Blue Jay carried some notes on efforts to locate exact sites of Fort Alexandria and Fort Hibernia. As nothing more has since been said on the matter, I thought I would bring the subject up to date and perhaps stir up some interest on the question of marking the location of historic sites.

To get some first hand information, I recently called on Bruce Peel, a librarian of Shortt Library of Candianna, at the University of Saskatchewan. Mr. Peel, who is also on the editorial board of that excellent periodical, The Saskatchewan History, kindly volunteered some pertinent facts and indicated sources dealing with the early days of the fur trade.

Much of the work of uncovering the sites of trading posts was done by the late Dr. Arthur S. Morton. His investigations into the early trading on the upper Assiniboine were carried out more than ten years ago and later were summarized in a paper published in the Transactions of the Royal Society of Canada.

Taking his clues from the astronomical observations of David Thompson and of Peter Fidler, and from references of sites in the records kept by the traders at the posts, Professor Morton was able to locate the remains of both Fort Alexandria and the Hudson's Bay Company's Carlton House, the two being built on contiguous sites, only 80 yards apart. The remains are to be found in S.W. $1 / 4-33-32-3-W 2$ nd. This is on the south bank of the Assiniboine River and about a mile downstream from the new bridge on No. 9 highway, some dozen miles north of Canora.

The two posts have a somewhat similar history; both were built in 1795, and except for short breaks remained in operation until 1821, when with the union of the two companies, all the outlying posts were pulled out and the whole trade of the Assiniboine and the Swan was centred at Fort Pelly. Carleton House, as such, remained in op- eration only until 1800 and when reopened in 1807 was renamed Fort Hibernia No. 2 to distinguish it from Fort Hibernia No. 1, located at the elbow of the Assiniboine.

Reading through the journal kept by Daniel Harmon, who was instrumental in setting up the North West Company post, one gets the impression that Fort Alexandria was or more than average importance. Harmon appears to have used it as a base of operations in his periodic expeditions into outlying country.

At about the same time, an $X Y$ Co's. post was in operation some five miles up the river. Professor Morton was unable to find any traces of it but he thought that it might have been incated on the East bank of the river near a ford in N.E. $1 / 4-12-33-4-$ W2rid. or possibly S.W.1/413. This post doesn't figure much in the records of the other two companies, although it undoubtedly was built to screen the Indian trade passing to its rivals down the river. If anyone reading this has any additional information on this post, I am sure it would be worth while to have it passed on to our readers. Tracing the location of this old trading post would indeed be a rewarding pastime.

Actually the above mentioned posts were only three out of more than a dozen, located on a fifty mile stretch of the river. Some of these were Marlborough House, Albany House, Grant's House and Fort Pelly, all of which operated at one time or another during the period 17901871. If we add to this number the establisments which operated on the Swan, the Red Deer and the Qu'Appelle Rivers, we get in North Eastern Saskatchewan one of the greatest concentrations of posts in the whole fur country,

This region was truly a happy hunting ground of the trapper and trader. David Thompson, the famed trader and geographer, passing through this country in 1797 writes, "The ground is wet from the many ponds, kept full by beaver dams." The remains of many of these dams 
are still in evidence, but today they stand high and dry and where once were ponds and rivulets are now fields of grain.

Besides the beaver and the otter, which provided the chief article of trade, the region teemed with game of all kinds. Harmon speaks of huge flocks of water fowl appearing in the spring and deer and moose being common all year round. The staple article of food, as elsewhere, was provided by the buffalo, whose herds every winter moved into this beautiful country of sheltered coulees and lush native vegetation to escape from the blizzards of the southern prairies.

Today, one hundred and fifty years later, the beaver and the buffalo are no more and all that is left of the traders' posts are cellar holes and a few chimney stones. Already whole new generations have grown up, who are entirely unaware of historic ruins lying practically in their back yards.

A suggestion has been made that the Highway Department or some other government agency erect suitable signs which would give some information on the historic sites nearby. Both of our sister provinces follow the practise of setting up name plates at all important river crossings. This idea could be adapted to include not only the name of the river but also something of its historic significance.

One of the pleasures incidental to motoring through a strange countryside is derived from having readily accessible information on points of interest along the way. This type of publicity would not only facilitate tourist traffic, but what is more im- portant, would be a tangible evidence of enlightened pride the people of Saskatchewan take in their rich historic past.

Where location is favorable, the territory in the vicinity of a site could be developed into a small park which would also be sort of a miniature wildlife sanctuary. Surely a small monument or an artistically done but inexpensive sign, set in attractive natural surroundings, would be but a modest tribute to the courage and resourcefulness of men who blazed a trail through the wilderness, a full century before the first settler turned a furrow.

\section{DANCING GROUND}

(Continued from page 15)

be one or two minutes they would begin a game of tag or make a running charge with lowered heads to take up positions similar to those of fighting roosters.

From a crouching position one pair was seen to exchange pecks at each other's heads. One of these birds soon wandered away and a few minutes later the bird who had been sitting quite still watching the car decided to join the party. $\mathrm{He}$ right wheeled, lowered his head and charged across the 100 feet on the run to the lone bird. We could almost imagine his yelling "look out here I come." But he pulled up two or three feet short of his opponent, crouched and began an out-glaring competition which was still in progress as we drove away.

We watched the performers for half an hour during which time eight of the eleven birds seen took part in the display.

\section{THE VANDALISM OF MAN}

"I $\mathbf{I}^{\mathrm{N}}$

$\mathrm{N}$ the scheme of natural things, each species fits into the pattern of balance. Never departing from their general habits, the wild children of the world synchronize into a perfect machine of succeeding useful things. Man is the only thing that will permanently throw the scheme out of gear, causing chaos and often great loss.

All the organizations for the conservation of wildlife are spending millions of dollars trying to patch up the vandalism of man. It's an endless and, perhaps, will be ultimately a hopeless task. It will then be viewed by the citizens of the world as a drab planet without the beauty and interest of things that live in the wild. Insecticides and poison will be the only protection against the ever increasing horde of insects that will ever threaten the very existence of man." -National Wildlife and Conservation Digest. 